\title{
Et grundtvigiansk fakultet
}

\section{Det teologiske fakultet i Christiania i dets første fase}

\author{
Professor Hallgeir Elstad ${ }^{1}$
}

Abstract: The aim of this article is to shed light on the founding phase of the history of The Faculty of Theology in Christiania (Oslo). Together with the University of Oslo the Faculty celebrates its 200 years anniversary in 2011. The University was the first cultural institution in Norway and played a decisive role in the nation building. The history of the Faculty of Theology is tightly interwoven with that of the University. The initial phase of the Faculty's history may be characterized 'Grundtvigian'. Despite of the break with Denmark in 1814, the Danish cultural influences were still strong.

Key words: Grundtvig - Hersleb - Stenersen - Norway - The University of Oslo - The Faculty of Theology.

I 2011 er det 200 år siden opprettelsen av et eget norsk universitet og med det også et teologisk fakultet og en teologisk utdannelse. Universitetet var Norges første kulturinstitusjon, og spilte en avgjørende rolle i den norske nasjonsbyggingen. Opprettelsen av universitetet skjedde kort før adskillelsen fra Danmark. Som følge av deltagelsen på Frankrikes side i napoleonskrigene, måtte Danmark oppgi Norge til Sverige ved Kieltraktaten i januar 1814. Norge benyttet anledningen til å utforme sin egen grunnlov våren 1814, den mest liberale i samtidens Europa. Etter en kort krig mot Sverige inngikk Norge i en ny - og løsere union - med Sverige. ${ }^{2}$

Grunnloven og universitetet ble to viktige nasjonale symboler for det nye Norge etter 1814. Universitetets historie følger det moderne Norges historie. Og Det teologiske fakultets historie er en del av hele universitetets historie. Hensikten med denne artikkelen er å gi en oversikt over opprettelsen av et norsk universitet i 1811 og primært

1. Forfatteren er ansatt ved Det teologiske fakultet, Universitetet i Oslo som professor i norsk kirkehistorie.

2. Om adskillelsen mellom Danmark og Norge, se f. eks. Ole Feldbæk, Narhed og adskillelse 1720-1814. Bind IV Danmark-Norge 1380-1814 (Oslo: Universitetsforlaget 1998), 311-403. 
følge grunnleggelsen og oppbyggingen av et norsk teologisk fakultet og en egen teologisk utdannelse atskilt fra Danmark. Københavns universitet hadde i 300 år også vært nordmennenes universitet. Nå skulle nordmennene også akademisk stå på egne ben. Men forbindelseslinjene til Danmark og Københavns universitet var likevel sterke, spesielt i den første fasen av det norske fakultetets historie.

\section{Et norsk universitet ${ }^{3}$}

Ved reskript av 2. september 1811 gikk den dansk-norske konge Frederik VI med på å opprette "et fuldstændigt Universitet" i Norge. ${ }^{4}$ Flere ganger hadde det norske kravet om eget universitet vært reist, men uten å vinne gehør hos den dansk-norske kongen. I 1809 kom spørsmålet opp på nytt. Den viktigste pådriveren for et norsk universitet i denne runden var det nystiftede Selskabet for Norges vel. En av dem som fikk en ledende rolle i arbeidet for et norsk universitet, var grev Herman Wedel-Jarlsberg, embetsmann og landets fremste adelsmann. Det ble utlyst en priskonkurranse, og resultatet ble offentliggjort tidlig i 1811 (Collett 2009, 164-176). Det ble delt ut tre priser - alle gikk til teologer. ${ }^{5}$ Nicolai Wergeland (1780-1848), adjunkt ved Kristiansands katedralskole, ble belønnet med førsteprisen for en avhandling med tittelen Mnemosyne. ${ }^{6}$ Wergeland argumenterte for at et universitet var nødvendig for enhver stat som ønsket å utvikle seg til en kulturnasjon. Norge kunne ikke være noe unntak. Wergelands avhandling reflekterte den pågående debatten i samtidens Europa om hvilken rolle og funksjon universitetene skulle ha i samfunnet. Wergelands vinnerskrift fikk svært god mottakelse i Norge, og viste

3. For nyere fremstillinger av opprettelsen av det norske universitetet, vises til John Peter Collett, Historien om Universitetet i Oslo (Oslo: Universitetsforlaget 1999); John Peter Collett, "Selskapet for Norges Vel og opprettelsen av Det Kongelige Frederiks Universitet”, i: John Peter Collet og Ernst Bjerke ed., Vekst gjennom kunnskap. Det Kongelige Selskap for Norges Vel 1809-1814 (Oslo: UniPub 2009), 159-200. I det dette skrives lanseres Universitetet i Oslos historie i 9 bind. Professor John Peter Collett er hovedredaktør for hele verket og har vært ansvarlig for det første bindet som omhandler perioden 1811-1870.

4. Fr. Aug. Wessel-Berg, Kongelige Rescripter, Resolutioner og Collegial-Breve for Norge $i$ Tidsrummet 1660-1813. Fjerde Bind 1797-1813 (Christiania: Cappelen 1845), 938-939.

5. Knut Aukrust, “Teologistudiet på norsk", Norsk Teologisk Tidsskrift 87 (1986), 19-21

6. Nicolai Wergeland, Mnemosyne. Et Forsøg paa at besvare den af Det kongl. Selskab for Norges Vel fremsatte Opgave om et Universitet i Norge. Et Priisskrift. Historiskphilosophiske Samlinger. (Christiania: Det kongelige Selskab for Norges Vel 1811). 
at kravet om et fullstendig universitet hadde stor oppslutning. Samtidig med priskonkurransen ble det iverksatt en stor pengeinnsamling for å skaffe den nødvendige startkapital for et universitet i Norge (Collett 1999, 30-45; Collett 2009, 177-182)

I Danmark var man skeptisk. For kongen var hensynet til helstatspolitikken avgjørende. Et eget universitet i Norge fryktet han ville virke splittende på unionsforholdet. Men samtidig kunne ikke kongen overse det engasjementet som ledende nordmenn la for dagen. De norske planene ble fremlagt for universitetsdireksjonen i København av grev Wedel. Han greide å overbevise danskene om nødvendigheten av å etablere et fullstendig universitet i Norge. Noe mindre enn dette kunne i nordmennene ikke akseptere, fremholdt Wedel. Bare et fullstendig universitet kunne påregne økonomisk støtte fra Norge (Collett 2009, 174-177).

Grev Wedels argumenter vant gjennomslag i universitetsdireksjonen, som gikk inn for å opprette et eget norsk universitet som primært skulle utdanne teologer, jurister og filologer. Man gikk inn for å legge universitetet til Kongsberg, men dermed ble det umulig å tilby et fullstendig medisinsk studium, siden byen ikke hadde et sykehus som kunne fylle kravene til klinisk undervisning for studentene. Men det kunne gis forberedende teoretisk undervisning i Norge før studiene ble fullført i København (Collett 2009, 176). Etter at den norske pengeinnsamlingen hadde vart i tre måneder, gav også kongen etter. 2. september $1811 \mathrm{kom}$ den formelle opprettelsen av et universitet i Norge (Collett 2009, 182).

Universitetskravet var en norsk hjertesak og ingen felles norskdansk sak. I sitt vinnerskrift var Nicolai Wergeland kritisk til den danske regjeringens politikk overfor Norge. Han hevdet at Norge var et eget rike på linje med Danmark, noe som ble til dels heftig imøtegått fra dansk hold. Den kritiske holdningen til Danmark kom for alvor til uttrykk i et anonymt skrift om Danmarks politiske Forbrydelser imod Kongeriget Norge. ${ }^{7}$ Det ble snart kjent at N. Wergeland var forfatteren. Innsigelsene denne gang kom ikke bare fra Danmark, men også fra nordmenn. ${ }^{8}$

Opprettelsen av universitetet ble møtt med norsk begeistring. I desember 1811 ble det arrangert en nasjonalfest over hele landet. De

7. En sandfardig Beretning om Danmarks politiske Forbrydelse imod Kongeriget Norge fra Aar 955 indtil 1814, eller fra Hakon Adelsteens Krig mod Harald Blaatand, indtil Fredslutningen i Kiel. En historisk Skisse (Norge 1816).

8. Blant dem som protesterte var teologiprofessor Svend Borchmann Hersleb, med skriftet Affordret Beviis for at Skriftet "Sandfardig Beretning om Danmarks politiske Forbrydelser imod Norge" - fortjener enhver retsindig Nordmands Uvillie og Foragt (Christiania 1817). 
fleste steder skjedde festmarkeringen i kirkene. Festlighetene fikk et sterkt nasjonalt tilsnitt. I festtalene, som ut over bygdene gjerne ble holdt av prestene, ble det understreket at universitetet ville få stor betydning for Norges fremtid (Collett 2009, 185-187).

\section{Hva slags universitet?}

Et viktig spørsmål var organiseringen av den norske universitetet. En egen kommisjon ble nedsatt for å utarbeide planer for den nye institusjonen. Nordmannen Niels Treschow (1751-1833), som var filosofiprofessor ved Københavns universitet, fikk sammen med tre andre nordmenn sete i kommisjonen. Rett over nyttår i 1812 kom kommisjonen sammen i København. Etter knappe tre måneder forelå innstillingen (Collett 2009, 193-196). Det ble gjort gjeldende at undervisningen ved den nye institusjonen skulle begynne fra sommeren 1813. Man så for seg at universitetet skulle være ferdig utbygd i løpet av to år - med en stab på 25 professorer. Kommisjonen tok som utgangspunkt at det norske universitetet skulle møte samtidens behov på en bedre måte enn tilfelle var med Københavns universitet. I stedet for de tradisjonelle fire fakultetene skulle det i Christiania være dobbelt så mange, blant annet et matematisk, et naturvitenskapelig og et økonomisk fakultet. For å uttykke takknemlighet overfor kongen, ble Det Kongelige Norske Fredriks Universitet foreslått som offisielt navn, eller Universitas Regia Fredericiana på latin. Kommisjonen foreslo å legge universitetet til Christiania, ikke Kongsberg. I Christiania fantes nemlig sykehus som gjorde det mulig å tilby medisinstudier. Dette fikk kongens godkjenning av 10. april 1812 (Wessel-Berg 1845, 976-978).

\section{Universitetet $i$ Christiania}

Det ble imidlertid ikke noe av de ambisiøse planene om åtte fakulteter. Da Det kgl. Frederiks Universitet i Christiania åpnet dørene høsten 1813, var det til forveksling lik Københavns universitet, med et teologisk, et juridisk, et medisinsk og et filosofisk fakultet. Som i København var universitetet i Christiania primært et profesjonsuniversitet, et embetsmannsuniversitet. Hovedoppgaven for det nye universitetet var å skaffe staten de embetsmennene den trengte. Dette gjorde det til en av de mest sentrale institusjonene i Norge. Embetsmennene fikk en helt grunnleggende posisjon i den nye staten. Gjennom sin utdannelse ervervet de kunnskap og dannelse som gjorde dem til en elite i samfunnet. I kraft av dette ble de den nye statens selvsagte ledere. Den norske historikeren Jens Arup Seip omtaler den norske staten 
i perioden 1814-1884 som "embetsmannsstaten".? Juristene hadde her en sentral rolle, men embetsmannsstaten var også en prestestat. ${ }^{10}$ Prestene hørte med til de viktige embetsmennene, og var representert i hvert lokalsamfunn over hele landet. Prestene var de av embetsmannsstanden som folk flest kom oftest i berøring med gjennom gudstjenester og ulike "kirkelige Forretninger".

Det første kullet som ble immatrikulert, talte 18 studenter. Lærerstaben bestod av fem professorer og en lektor - i teologi. Flere hadde bakgrunn fra Københavns universitet, således Niels Treschow og Georg Sverdrup (1770-1850) som var professorer i henholdsvis filosofi og gresk. Sistnevne virket også som universitetsbibliotekar. De seks første universitetslærerne ble ansatt 16 . januar $1813 .{ }^{11}$ Universitetet i Christiania begynte sin virksomhet uten at det var utarbeidet en egen fundas. Man bygde på planen fra $1812 \mathrm{og}$ fundasen ved Københavns universitet. Først i 1824 fikk Universitetet i Christiania sin egen fundas (Morgenstierne 1911, 39, 60-101).

Første fase: Det grundtvigianske fakultet (1813-ca. 1850)

I den første runden med ansettelser - i januar 1813 - var det, som nevnt, blitt utnevnt til et lektorat i teologi. Teologien ble således ikke tilgodesett med et professorat i første omgang, noe som kunne tyde på at man i utgangspunktet ikke tiltenkte teologifaget den mest fremtredende plass ved det nye universitetet. Det viste seg heller ikke å være lett å skaffe lærere i teologi. Etablerte teologer i København professorene Peter Krog Meyer, som for øvrig var født i Norge, Jens Møller, Peter Erasmus Müller og den senere biskop Jakob Peter Mynster - ble forespurt, men takket alle nei. ${ }^{12}$ Universitetet i Christiania måtte dermed ta til takke med to unge og ukjente nordmenn som de første lærere i teologi.

Den 29-årige Sven Borchmann Hersleb (1784-1836) ble utnevnt i lektorstillingen - i teologi og hebraisk. Han var født i Alstadhaug i Nordland, ble student fra katedralskolen i Trondheim i 1802 og fullførte teologisk embetseksamen ved Københavns universitet i 1807. Fra 1808 til sin ansettelse var han adjunkt ved "Frue Skole" i København. I juni 1814 fikk Hersleb utnevnelse til professor. Ved samme

9. Jens Arup Seip, Utsikt over Norges historie. Første del (Oslo: Gyldendal 1974), 11.

10. Rune Slagstad, De nasjonale strateger (Oslo: Pax 1998), 26-27.

11. Bredo Morgenstierne, "Universitetet fra 1813 til 1911", Det kongelige Fredriks Universitet 1811-1911. Festskrift I (Kristiania: Aschehoug 1911), 3.

12. Einar Molland, Norges kirkehistorie i det 19. arrhundre. Bd. 1 (Oslo: Gyldendal 1979), 106. 
anledning ble den 25 år gamle Stener Johannes Stenersen (17891835) - kateket ved Vor Frelsers kirke i Christiania - utnevnt til lektor i teologi. Han var født på Jevnaker ved Randsfjorden. Etter å ha gått på katedralskolen i Christiania, tok han i 1808 eksamen artium ved København universitet og ble teologisk kandidat i 1811.13

Det var således to - faglig sett - ubeskrevne blad som fikk oppgaven med å bygge opp en teologisk universitetsutdanning fra grunnen av i Norge. Inntil 1832 var disse to de eneste lærerne ved Det teologiske fakultet. De fordelte fagkretsen seg i mellom slik at Hersleb fikk ansvaret for den gammeltestamentlige og systematiske teologien, mens Stenersen overtok Det nye testamente og kirkehistorien. Undervisningsbelastningen var stor. Hersleb kunne forelese opptil 20 timer i uken (Brandrud 1911, 209). Han var den av de to som tok seg mest av de administrative oppgavene. Etter 1814 var fakultetet høringsinstans i kirkelige og teologiske spørsmål, og det medførte en omfattende arbeidsbyrde i tillegg til forelesningsplikten. Derfor hadde han heller ingen stor faglig produksjon. ${ }^{14}$

Stenersen derimot hadde et anselig forfatterskap. Han skrev flere kommentarer til nytestamentlige skrifter. Mest omfattende var hans kommentar i fire bind til Paulus-brevene på latin. Som kirkehistorisk forfatter skrev han bindsterke verk om reformasjonshistorie og allmenn kirkehistorie. Hans mest originale arbeid, om vekkelseslederen og legmannspredikanten Hans Nielsen Hauge, ble utgitt i 1827, bare tre år etter Hauges død. Han tegnet et positivt bilde av den norske legmannsvekkelsens grunnlegger, men stilte seg kritisk til hans offentlige forkynnervirksomhet. Hauge mente han selv var "kaldet til Lærer", men "han foer vild i denne sin Overbeviisning", hevdet Stenersen. ${ }^{15}$ Presteembetets enerett til den offentlige forkynnelse i kirken hadde guddommelig opprinnelse:

Denne Skik eller denne Indretning, at Læren vorder offentlig forkyndt i Kirken allene ved visse dertil bestemte og indviede Lærere, og at i de

13. Når det gjelder Hersleb og Stenersens biografier, se Hallgeir Elstad, "Svend Borchmann Hersleb”, i: Jon Gunnar Arntzen ed., Norsk biografisk leksikon. Bd. 4 (Oslo: Kunnskapsforlaget 2001); Hallgeir Elstad, "Stener Johannes Stenersen”, i: Jon Gunnar Arntzen ed., Norsk biografisk leksikon. Bd. 8 (Oslo: Kunnskapsforlaget 2004). Se for øvrig Andreas Brandrud, “Teologien ved det norske universitet 18111911”, Norsk Teologisk Tidsskrift 12 (1911), 201-280; Einar Molland, "Det teologiske fakultets historie 1811-1961”, Norsk Teologisk Tidsskrift 63 (1962), 273-297.

14. Men hans bibelhistoriske lærebok, første gang utgitt i 1812, var nesten enerådende som lærebok i den høyere skole inntil ca. 1850. Svend Borchmann Hersleb, Larebog i Bibelhistorien udarbeidet isar med Hensyn paa de høiere Religionsklasser $i$ de larde Skoler (København: Brummer 1812).

15. Stener J. Stenersen, Hans Nielsen Hauges Liv, Virksomhed, Lare og Skrifter (Kjøbenhavn 1827), 90. 
Menigheder, som de ere ansatte til at vaage over, Ingen uden deres Minde og Tilladelse maa tiltage sig at lære offentligen, er ingenlunde ny, (...) men er meget mere ligesaa gammel som Kirken selv, og kan derfor heller ikke siges at være af menneskelig men guddommelig Oprindelse. (Stenersen 1827, 90-91)

Under Hersleb og Stenersen uttalte Det teologiske fakultet seg i mot å oppheve konventikkelplakaten av $1741 .{ }^{16}$ Denne negative holdningen til legmannsforkynnelse kom til å prege den nye prestegenerasjonen utdannet i Norge. Prestenes forhold til legmannsbevegelsen ble for en stor del preget av avstand og til en viss grad også motsetninger (Molland 1979, 110).

\section{"De vigtigste i Verden"}

Det teologiske fakultet ble opprettet i en tid da reaksjonen mot opplysningen gjorde seg gjeldende i Europa og Norden - gjennom romantikk og konfesjonalisme. Både Hersleb og Stenersen var preget av disse strømningene. Den norske kirkehistorikeren Einar Molland kaller dem "restaurasjonsteologiens menn" (Molland 1979, 106). de nye lærerne i teologi var influert av N.F.S. Grundtvig. De stod sammen med Grundtvig i hans oppgjør med rasjonalismen, $\mathrm{i}$ hans bibelkristne fase. Hersleb og Grundtvig var venner fra tiden i København hvor begge bodde på Valkendorfs kollegium (Brandrud 1911, 204-205). Stenersen var likeledes preget av den romantisk-religiøse reaksjon mot opplysningen, og brevvekslet med Grundtvig gjennom mange år. Blant annet under påvirkning fra Grundtvig nådde Stenersen frem til et bibelkristent standpunkt med luthersk-konfesjonelt preg. Den teologiske profil ved Det teologiske fakultet i Christiania var således en ganske annen enn ved fakultetet i København, hvor opplysningsteologien fremdeles var den toneangivende. ${ }^{17}$ Grundtvig hadde stor tro på "Norges Høiskole". I 1814 skrev han i et brev til Stenersen at de to norske universitetslærerne "nu beklæde de Embeder, jeg for min Part anseer for at være, uden al Overdrivelse, de vigtigste i Verden, thi Norges Høiskole er for mig den, hvorfra sand Christelig Theologi igjen skal udgaae i Verden."18

16. Andreas Seierstad, Kyrkjelegt Reformarbeid i Norig i Nittande Hundreaaret. Fyrste bandet. Norvegia Sacra (Bergen: Lunde 1923), 264.

17. Knud Banning, “Det teologiske fakultet 1732-1830”, i: Leif Grane ed., Det teologiske fakultet. Bd. V: Københavns Universitet 1479-1979 (Købehavn: G.E.C. Gads forlag 1980), 283-323.

18. Sitert etter Anders Skrondal, Grundtvig og Noreg. Kyrkje og skule 1812-1872. Bibliotheca Norvegiæ Sacræ (Bergen: Lunde 1929), 48. 
Luthersk bibelteologi kom altså til å prege Det teologiske fakultet under Hersleb og Stenersen. Den grundtvigianske innflytelsen var vesentlig i de første grunnleggende årene av fakultetets historie. Det var til og med på tale å ansette Grundtvig i en lærerpost i historie og som universitetsprest ved det norske universitetet. Både Hersleb og greskprofessor Georg Sverdrup gikk inn for dette. Forslaget ble reist både i 1812 og i 1816, men uten at det førte til noe. Også filosofiprofessor Niels Treschow hadde et positivt forhold til Grundtvig, men det kjølnet med tiden. Han ble kritisk til den mer pågående forkynnelsen fra Grundtvigs side etter dimissprekenen i 1810, "Hvi er Herrens Ord forsvundet af hans Hus?”. Når Grundtvig ikke ble knyttet til universitetet i Christiania, var det vesentlig fordi Treschow, som høsten 1814 var blitt kirkestatsråd, motsatte seg det (Molland 1979, 115). Man kan jo fristes til å spekulere over hva det ville betydd om Grundtvig hadde blitt professor i Christiania!

Grundtvigs innflytelse i Norge var betydelig. Hans historiesyn fant tilslutning blant flere i en kulturelle og akademiske eliten. Blant dem hørte for eksempel de to professorene Niels Treschow og Georg Sverdrup. Grundtvigs kamp mot rasjonalismen gav ham sympatisører blant haugianerne, det kristne legfolket i Norge. Hans Nielsen Hauge hadde selv lest flere av hans skrifter, og sendte ham også en pengegave på 530 riksbankdaler - for datiden ingen ubetydelig sum - i takknemlighet for det gode han og hans haugianske venner hadde mottatt gjennom hans skrifter (Skrondal 1929, 54-55). Grundtvig selv hadde sympati med den haugianske bevegelse. "Med Hans Nielsen Hauge vaagnede Folkeaanden i Norge", uttalte han så sent som i 1850 (Skrondal 1929, 55).

Det nære forhold mellom de to første lærerne ved Det teologiske fakultet og Grundtvig kjølnet imidlertid etter at Grundtvig i 1825 kom frem til sin såkalte "mageløse Opdagelse". I stridsskriftet Kirkens Genmale, som var rettet mot København-professor H.N. Clausens store verk om "Katholisismens og Protestantismens Kirkeforfatning, Lære og Ritus", utkommet tidligere samme år, angrep Grundtvig Clausens understrekning av nødvendigheten av den frie kritikk av Skriften. Ifølge Grundtvig stilte Clausen seg på samme side som "den kristelige Kirkes Fjender og Guds Ords Foragtere i Landet”. Clausen innførte et nytt "eksegetisk pavedømme" for legfolket, men kirken kunne imidlertid ikke bygge på skrifttolkninger som endret seg gjennom tidene. Den opprinnelige kristendom måtte derimot søkes i den apostoliske trosbekjennelse, fordi denne stammet direkte fra Kristus. 
Dermed var Kristus selv til stede i sitt ord i menigheten, som var samlet om døpefont og nattverdbord. ${ }^{19}$

Denne "kirkelige anskuelse" kunne ikke Hersleb og Stenersen gi sin støtte. De holdt fast på Bibelen som troens - og kirkens - grunnlag. Men deres biblisisme var på ingen måte noen ekstremvariant. De hadde syn for det historisk betingede i Bibelen, og at den også kunne inneholde uhistoriske trekk. Stenersen polemiserte offentlig mot "anskuelsen", og Grundtvig uttalte seg etter hvert med skuffelse over nordmennene. Hersleb "farer vild eller er standset paa Halv-Vejen", skrev han $\mathrm{i}$ et brev til den fremste grundtvigianeren i Norge, W. A. Wexels. Og med Stenersen stod det enda verre til: "Ham maa jeg indtil videre glemme", skrev Grundtvig. ${ }^{20}$ Noe av Grundtvigs skuffelse over Hersleb og Stenersen og Det teologiske fakultetet handlet også om den retning som presteutdannelsen i Christiania kom til å utvikle seg i. Hersleb og Stenersen delte ikke Grundtvigs begeistring for den nordiske folkeånd. De fortsatte den akademiske tradisjon med å undervise på latin - og forutsatte hele den klassiske dannelse som basis for prestestudiet. De var ikke annet enn "prestemagere", uttalte Grundtvig i sin frustrasjon over nordmennene (Christensen og Grundtvig 1926, 266).

Hersleb og Stenersen bidro til å danne en ny norsk prestegenerasjon etter 1814. Fra 1820-årene av begynte de "Hersleb-Stenerske prestene" å fylle de geistlige embetene. Mange av den eldre prestegenerasjonen takket av mot slutten av 1820 -årene. I 1835 var tre fjerdedeler av prestene som satt $\mathrm{i}$ embete, utdannet ved Det teologiske fakultet. Einar Molland hevder at dette er det mest markerte generasjonsskifte i den norske prestestandens historie siden reformasjonen (Molland 1979, 113).

Til tross for Hersleb og Stenersens brudd med Grundtvig fortsatte den grundtvigianske innflytelsen å gjøre seg gjeldende. Flere av den nye prestegenerasjonen ble påvirket av Grundtvigs tanker både før og etter 1825. Mange norske teologer fulgte interessert med på Grundtvigs kirkekamp i Danmark. Også Norge skulle få sin variant av den grundtvigiansk kirkekamp. Det skal vi komme tilbake til. La oss imidlertid først gå tilbake til det norske universitets og det teologiske fakultets aller første tid.

19. Se Dag Thorkildsen, Grundtvigianisme og nasjonalisme i Norge i det 19. arrhundre. KULTs skriftserie nr. 70 (Oslo: Norges Forskningsråd 1996), 39-43.

20. Georg Christensen og Stener Grundtvig ed., Breve fra og til N.F.S. Grundtvig. Bd. II (1821-1872) (København: Gyldendalske boghandel 1926), 128. 


\section{Oppstart under kummerlige forhold}

Virksomheten Universitetet startet under kummerlige forhold. Til å begynne med fantes ikke et universitetsbibliotek. Den engelske blokaden av sjøveien mellom København og Norge på grunn av Napoleonskrigene giorde det umulig å få sendt bøkene opp fra København. Det var heller ikke mye av personlige eiendeler universitetslærerne hadde fått med seg. I et brev fortalte Hersleb at det første semesteret han underviste, hadde han sju bøker til rådighet - og ingen manuskripter eller notater. Alt var blitt etterlatt i København (Morgenstierne 1911, 19).

Til å begynne med var det heller ikke mange studenter som fulgte de teologiske forelesningene. I et brev fra november 1813 gav Hersleb følgende situasjonsrapport fra undervisningen det første semesteret:

Jeg læser over Amos, Dommernes Bog, Indledning til det hebraiske Sprog og theologisk Encyklopædie og har 10 Studenter, som høre mig den første og fjerde Forelæsning har jeg ogsaa 3 Candidater som Tilhørere af (Sitert etter Morgenstierne 1911, 17).

Hersleb gav imidlertid inntrykk av å være fornøyd i sin nye stilling. Arbeidet tok det meste av hans tid, men han trivdes. "Jeg kommer næsten ikke til Nogen uden til Sverdrup og Treschow og har meget at bestille, men finder min Syssel usigelig interessant og er hjertelig glad ved at kunne leve blot for mit Yndlings-Studium. Stod det saa godt til med Fædrelandet som med mig, var jeg lykkelig", skrev han i et brev (Morgenstierne 1911, 18). Han hadde omgang med professorene Treschow og Sverdrup, som faglig sett stod ham nærmest (filosofi og klassiske språk). ${ }^{21}$

Den første teologiske embetseksamen - og den første embetseksamen ved det nyopprettede universitetet overhodet - ble avholdt i slutten av april 1815, knappe to år etter oppstarten. Tre kandidater var oppe til eksamen, i Katedralskolens store auditorium. Slottsprest Claus Pavels (1769-1822) var tilhører, og beskriver eksamensgjennomføringen i sin dagbok. Universitetets prokansler, biskop Frederik Julius Bech (1758-1822), innledet eksaminasjonen. "Hans Examination kunde passende lignes ved en tynd, flau Suppe, hvoraf vi endda paanødedes en overdreven Portion", noterte Pavels skadefro i dagboken. Mens professor Hersleb "tracterede (for at blive i Lignelsen) med godt, solid, saftigt Kjød, men uden Sauce og med lidet Salt. Stenersen gav en delicat Ragout (...) Han var en ypperlig Examinator.

21. Hersleb var for øvrig i slekt med Sverdrup, som var fetter til Herslebs far. 
Han talte godt Latin, og der var Liv i hans Foredrag; han satte ogsaa Mod i Candidaten, saa det blev til et virkelig interessant Colloquium. Han er upaatvivlelig langt mere paa sin Hylde nu, end da han prædikede Schellingsk Philosophi for en Snes ucultiverede Mennesker i Byens Kirke."22

Neste gang teologisk embetseksamen ble arrangert, var i juni samme år. Pavels var da sensor - for en kandidat, Peter W. Deinboll. Eksaminatorer var de samme som ved den forrige eksamen. Biskop Bech eksaminerte over "det nye Testamentes Exegetik, og gik derfra over til den naturlige Theologi og Moral". Kandidaten hadde vært syk - ifølge Pavels fordi han hadde tatt det for hardt med studiene og var ikke helt kommet til hektene igjen. Under eksaminasjonen fikk han "omsider ondt, svedte Angstens Sved, tabte næsten baade Mæle og Bevidsthed og maatte ud at tage frisk Luft." Da kandidaten kom inn igjen, kunne eksaminasjonen fortsette. Det gikk gradvis bedre, og han oppnådde til slutt en laud (Riis 1867, 120-122). Deinboll var for øvrig dansk, født i København, og hadde påbegynt sine studier der. Han var lærer flere steder i Norge før han i 1814 ble immatrikulert ved universitetet i Christiania. Samme år som han fullførte teologisk embetseksamen, ble han utnevnt til sogneprest i Vadsø i Øst-Finnmark, og ble senere også prost og var i flere perioder stortingsrepresentant. ${ }^{23}$

Dette var de to teologiske embetseksamenene som ble gjennomført i 1815 - for i alt fire studenter. Det var bestemt at det skulle holdes tre teologiske embetseksamener i året: januar-februar, mai-juni og august-september. Allerede høsten 1814 ble det for første gang holdt homiletisk prøve (eksamenspreken kalt dimisspreken) og dernest i februar 1815. De tre kandidatene som holdt dimisspreken ved disse to anledningene, hadde avlagt den teoretiske delen av embetseksamen ved universitetet i København.

Kollegiet bestemte at studenter som hadde påbegynt sine teologistudier i København, måtte fullføre embetseksamen innen 1. august 1816 for å få embete i Norge. Fra samme tidspunkt måtte alle embetseksamener avlegges ved universitetet i Christiania (Morgenstierne 1911, 39-40). Etter denne tid ble dermed heller ikke embetseksamen fra København godtatt som grunnlag for å søke prestetjeneste i Norge. Etter 1814 opphørte naturlig nok også unionstidens "frie flyt" av embetsmenn mellom Danmark og Norge. Det førte til prestemangel, fordi Norge i utgangspunktet ikke var selvforsynt med

22. C. P. Riis, Claus Pavels's Dagbogs-Optegnelser 1815-1816 (Christiania: Cappelen 1867), 72-73.

23. Ola Skifte, "Peter Deinboll”, Jon Gunnar Arntzen ed., Norsk biografisk leksikon. Bd. 2 (Oslo: Kunnskapsforlaget 2000). 
prester. I Det teologiske fakultets første tid var det liten tilgang på teologiske studenter, og dermed ble det ikke utdannet et tilstrekkelig antall kandidater i forhold til behovet. Som vi så ovenfor, var de første uteksaminerte kullene små. I perioden fra 1815 til 1824 ble det ut 82 kandidater fra Det teologiske fakultet. Fra midten av 1820-årene økte imidlertid antallet betraktelig. I årene fra 1823 til 1832 var det samlede kandidattallet 277.24 Det teologiske fakultet var dermed det største fakultetet ved Universitetet i Christiania.

Mangelen på embetsmenn i Norge etter 1814 førte til at det for jurister og medisinere ble redusert på kravet til klassisk dannelse. Embetseksamen for disse to profesjonene ble åpnet for dem som ikke var akademiske borgere, dvs. ikke hadde latinskole og eksamen artium og som dermed heller ikke kunne ta embetseksamen på latin. Det ble innført en såkalt "præliminærexamen" til erstatning for eksamen artium, uten latin. Men hva med teologene? Det var også stor prestemangel, i sær i Nord-Norge. Biskopen over det nordligste stiftet, Mathias B. Krogh (1754-1828), som for øvrig hadde vunnet andrepremien i priskonkurransen om et norsk universitet, tok til orde for å gi "ustuderede" teologer adgang til de "ringere geistlige Embeder i Nordlandene og Finnmarken". I 1817 ble forslag om dette sendt over til Det akademiske kollegium for uttalelse, og det påfølgende år kom saken til høring hos rikets biskoper. Forslaget møtte sterk motstand fra kollegiet så vel som fra biskopene. ${ }^{25}$ Man så ikke for seg teologisk embetseksamen uten latin. Den hørte med til de dannelseskrav som måtte gjelde for den geistlige embetsstand. De latinske ferdigheter ble sett på som grunnleggende for teologer - i motsetning til jurister og medisinere. Dette viser med tydelighet at det var de rent teoretiske krav om klassisk dannelse som ble vektlagt.

Slik teologistudiet ble drevet, var latin en nødvendighet. De teologiske forelesningene ble for en stor del gitt på latin i 1820- og 30-årene. Det heter om professor Herslebs forelesninger at de "var utarbeidede - de fleste paa glimrende latin”. Det ble imidlertid også forelest på norsk. For eksempel holdt lektor Stenersen i 1816 alle sine forelesninger "paa Modersmaalet" - riktignok fordi han ikke hadde hatt tid til å utarbeide dem på latin. Til teologiske embetseksamen ble alle seks skriftlige oppgaver gitt og besvart på latin. Det var også forutsetningen at den muntlige eksaminasjonen skulle foregå på denne språkformen, men de "som ei formaa at udtrykke sig nogenlunde

24. Carsten Elmelund Petersen, Troens Gerning (Oslo: Solum 1997), 180-181.

25. Morgenstierne 1911, 42; Vidar L. Haanes, "Hvad skal da dette blive for prester?", Presteutdannelsen $i$ spenningsfeltet mellom universitet og kirke, med vekt $p a ̊$ modernitetens gjennombrudd i Norge. KIFO Perspektiv nr. 5 (Trondheim: Tapir 1998), 71-74. 
klart paa Latin" kunne delvis bli eksaminert på norsk. Det var nok ikke uten besvær at den vanlige student ble eksaminert på latin (Morgenstierne 1911, 195-196; Haanes 1998, 83).

Latinens posisjon ble gradvis svekket. Det nye artiumsreglementet $\mathrm{i}$ 1826 reduserte latinpensumet ved de lærde skoler, med den konsekvens at studentene fikk mindre øvelse i å anvende latin. Dette førte igjen til at det ble stadig vanskeligere å opprettholde latin som skriftlig og muntlig eksamensspråk ved universitetet. Mot slutten av 1830årene var latinen så godt som fjernet fra teologisk embetseksamen. I 1834 var siste gang en kandidat avla hele embetseksamen på latin, både skriftlig og muntlig. Fra omtrent 1840 var latinen i praksis avskaffet ved teologisk embetseksamen, selv om de skriftlige oppgavene fortsatt ble gitt på latin. Fra 1846 opphørte latinen formelt som språk ved skriftlig eksamen (Morgenstierne 1911, 199-201).

Diskusjonen om latinens stilling hadde for alvor begynt i 1830-årene. Det ble argumenterte for at de klassiske språk fikk en altfor dominerende plass i utdannelsen, Striden om den klassiske dannelse var imidlertid ikke bare et norsk fenomen. I hele Vest-Europa var man opptatt av spørsmålet. I Danmark gikk Grundtvig til harde angrep på latinen, og i Sverige gikk en rekke skolefolk til felts mot latinens dominans.

Grundtvig hadde også innflytelse på den norske debatten. Han mente at presteutdannelsen befant seg i krise, fordi den ikke svarte til tidens behov. Han ønsket folkelige prester, som heller enn å være dyktige i latin, skulle formidle bibelfortellingene til menighetene og lede gudstjenestene. Grundtvig la vekt på den praktiske teologi. Han hadde hatt store forhåpninger til det norske universitet og Det teologiske fakultet, men syntes de hadde sviktet. De forble med å dosere latin - i stedet for å være opptatt av den nordiske folkeånd. Grundtvig var sterkt i mot latinskolen og dens ensidige fokus på undervisning av gresk og latin. I 1837 publiserte han skriftet Til Nordmand om en Norsk Høiskole, hvor han tok til orde for opprettelsen av en folkelig høyskole i Norge tuftet på idealet om de nordiske folks kall til åndelig selvstendighet. Den grundtvigianske folkehøyskole videreførte tanken om folkespråket som grunnleggende for folkets dannelse og opplysning (Morgenstierne 1911, 196-199; Molland 1979, 123-124; Thorkildsen 1996, 50-53).

\section{Innhold $i$ teologistudiet}

Det teologiske fakultet fikk først en offisiell studieplan i 1832. Men Hersleb og Stenersen hadde imidlertid utarbeidet foreløpige studieplaner. I 1817 forelå et forslag som i hovedtrekk bestod av to hoved- 
fag for et teologisk studium som var beregnet til to og et halvt års varighet. Bibelfag var det ene av disse, og her ble det lagt opp til en fullstendig innføring i bibelhistorien. Det andre hovedfaget var systematisk teologi, som omfattet "den christelige Troslære og Moral i forbindelse med en kort fremstilling af Den almindelige Sædelære og, og den naturlige Religion, samt Dogmernes Historie." Kirkehistorien ble ikke regnet som noe egentlig hovedfag, men et "støttefag" som skulle leses sammen med verdenshistorien (Aukrust 1986, 30).

I "Studieplan for dem, der ville studere Theologie ved det Kongelige Fredriks Universitet i Tidsløbet 1825-1828” holdes det frem bestemte idealer som måtte gjelde for dem som skulle studere teologi. Utgangspunktet er at alle vitenskaper på grunnleggende måte utgjør en enhet. En "sand videnskabelig Dannelse" er noe mer enn å huske det man leser eller hører. Det er å tilegne seg "en egen levende Erkjendelse af Sandheden". Dermed er det akademiske studium ikke bare en forberedelse til selve utøvelsen av en fremtidig stilling eller kall, men også en forberedelse til videre og "mere individuell videnskabelig Virksomhed" etter at den formelle utdannelse er fullført. Idealet er altså at den faglige virksomhet ikke opphører ved embetseksamen, men videreføres etter endt studium. Studentene blir videre oppfordret til, mens de er ved universitetet, til å bruke enhver andledning til "at forøge deres Kundskaber, udvide deres Synskreds og uddanne deres Anlæg, uden dog derfor at tabe deres nærmeste Formaal af Sigte." Dannelsesidealet er fordypning så vel som faglig bredde. Som et tredje punkt minner studieplanen om sammenhengen mellom teoretisk studium og praktisk liv:

De theologiske Studerende ville endeligen ingensinde glemme, at den Indsigt, de erhverve sig, først da er levende, naar den afpræger sig i deres Forhold, og at den er uværdig og uduelig til det Kald, for hvilket han danner sig, der ei med grundig Indsigt forener Gudsfrygt og rene Sæ$\operatorname{der}^{26}$

Studieplanen skisserer et rimelig ambisiøst opplegg når det gjelder tilegnelsen av "Forkundskaber" som forberedelse og forutsetning for teologistuduet. Språkfagene er her avgjørende. må "vedligeholde og udvide grundig grammatikalsk Kundskab i det græske, latinske og hebraiske Sprog". De må dessuten at tilegnet seg "en klar Oversigt af den almindelige Verdens-Historie" og ha kjennskap til "vigtige Dele af Philosophien". Det var en forutsetning at studentene skulle kunne 
lese og forstå "det tydske Sprog", men det ville være nyttig om man også hadde kjennskap til "flere af de nyere Sprog" (Holmboe 1835, 190).

Faglig bredde hørte med til forutsetningene som studieplanen regnet med. Det var selvsagt at studentene fulgte de teologiske forelesningene. I tillegg oppfordret studieplanen dem til "at bivaane philologiske, philosophiske og historiske Forelæsninger, samt benytte de literaire Hjælpemidler, Universitetet tilbyder, ligesom og flittigen øve sig i at tale og skrive Latin." (Holmboe 1835, 191).

Vekten ble lagt på den teoretiske side av teologistudiet. Lite ble gjort for studentenes praktisk-teologiske utdannelse. Først og fremst var dette et ressursspørsmål. Hersleb og Stenersen hadde mer enn nok med den teoretiske undervisningen, og den praktiske teologi ble nedprioritert. I tillegg kom at de teologiske kandidatene reiste fra universitetet straks de var ferdig med embetseksamen, slik at det ble vanskelig å tilby noen form tilleggsutdannelse i praktisk teologi. Den såkalte dimissprekenen (prøvepreken) og en kateketisk prøve forble dermed den praktisk-teologske utdannelse for teologene.

Fraværet av praktisk teologi som en organisert del av teologistudiet kommer tydelig til uttrykk i teologisk studieplan for 1825-28:

Da de nærværende Omstendigheder ei tillade, at den practiske Theologie i Forelæsninger ved Universitetet kan blive foredragen, saa forventes, at de, der opofre sig til det theologiske Studium, ville under deres Ophold ved Universitetet, især efter at have tilendebragt deres Forberedelse til den theoretiske Examen, samvittighedsfuldt benytte enhver Anledning til ogsaa i denne Henseende at danne sig til duelige Kirkens og Statens Tjenere (Holmboe 1835, 194).

\section{Praktisk teologi}

Det teologiske fakultet understreket altså den klassiske dannelse. Gode forkunnskaper i gresk og hebraisk ble sett på som helt avgjørende for arbeidet med de eksegetiske disipliner. Vektleggingen av det klassiske utdannelsesideal førte til at oppmerksomheten i teologistudiet i det vesentlige ble konsentrert om teoretisk ferdigheter. Den praktiske side ved utdannelsen ble først gradvis satt på dagsorden. Rundt 1830 kom dette spørsmål i fokus. Flere tok til orde for teologenes behov for praktisk øvelse som del av deres forberedelse til prestetjenesten. I 1830 var et privat lovforslag om dette blitt reist i Stortinget, og i 1833 foreslo Det teologiske fakultet å opprette et praktisk-teologisk seminar. Det ble realisert i 1834, men uten å knytte det til Universitetet på tilsvarende måte som det filologiske seminar. Det meste av undervisningen ble allikevel besørget av professorene ved teologisk 
fakultet. Hersleb underviste i homiletikk, Stenersen i kateketikk. Lærere utenfra ble ansvarlig for undervisningen i kirkerett og musikk. ${ }^{27}$

Seminaret ble imidlertid ingen suksess. Oppslutningen om undervisningen fra studentenes side viste seg å bli mindre enn forventet. Trolig var årsaken at undervisningen ikke var obligatorisk, og det var heller ingen eksamen ved seminaret. Man hadde ikke gått inn på dette av hensyn til de teologiske studentenes økonomiske situasjon. Et obligatorisk praktisk-teologisk seminar ville forlenge presteutdannelsen og dermed gjøre den dyrere for studentene. Det viste seg også å bli et problem å skaffe forelesere. Professor Stenersen ble syk og døde allerede året etter opprettelsen, Herslebs virketid ved seminaret ble to år (Elstad 1998, 16-17).

\section{Grundtvigiansk kirkekamp - i Norge}

Den ledende grundtvigianer i Norge fra slutten av 1820-årene, var presten W.A. Wexels (1797-1866). Han var dansk, flyttet til Norge og studerte teologi ved fakultetet i Christiania - under Hersleb og Stenersen. I 1818 avla han embetseksamen. Deretter ble han kateket i Vor Frelsers kirke, senere residerende kapellan samme sted. Den ledende professor ved universitetet, Niels Treschow, utgav i 1828 boken Christendommens Aand, hvor han fremla et kristendomssyn som var klart opplysningspreget. ${ }^{28}$ Han avviste Kristi guddom og gav en omtolkning av flere dogmer, som han omtalte som "metaphysiske Spidsfindigheder". Boken vakte ikke så liten oppsikt blant representantene for den bibelkristne retningen. Professorene Hersleb og Stenersen ønsket ikke å polemisere mot sin høyt ansette kollega. Wexels tok imidlertid stridshansken opp. ${ }^{29}$ Den som benekter Kristi guddom, fornekter den tro som den kristne kirke har bekjent fra begynnelsen av, hevdet Wexels, som måtte tåle sterk kritikk fra opplysningshold. Det kristne lekfolket gav på sin side støtte til Wexels' kamp for bibelsk kristendom - slik de også hadde sympatisert med Grundtvigs kirkekamp tidligere.

27. Hallgeir Elstad, “...midt i den norske kirke...”, Det praktisk-teologiske seminar gjennom 150 år, 1848-1998. Det praktisk-teologiske seminars skriftserie nr. 3 (Oslo: Det praktisk-teologiske seminar 1998), 15-16.

28. Niels Treschow, Christendommens Aand, eller Den evangeliske Lare frimodig og upartisk beskreven (Christiania: Grøndahl 1828).

29. Wilhelm Andreas Wexels, Tanker over og i Anledning af Hr. Statsraad Treschows Bog om "Christendommens Aand eller den evangeliske Lare". Udgivne i Breve som et Gjenmale mod bemeldte Bog (Christiania: Cappelen 1828). I Wexels' valg av ordet "Gjenmæle" i undertittelen lød et ekko fra Grundtvigs eget kampskrift, Kirkens Gienmale (1825). 
Men denne allianse mellom grundtvigianismen og det troende lekfolket skulle imidlertid snart slå sprekker. Den utløsende faktor var arbeidet med en ny utgave av den gamle Pontoppidans forklaring, Sandhed til Gudfrygtighed. De to nye professorene ved teologisk fakultet, C.N. Keyser og J.M.P. Kaurin (se nedenfor), som begge var sympatisk innstilte overfor grundtvigianismen, hadde fătt oppgaven med å gjennomføre revisjonsarbeidet. De insisterte på å få med også Wexels i arbeidet. Forslaget fra disse tre forelå våren 1842, og året etter ble den nye utgaven autorisert til bruk i skolen. Men boken møtte sterk motstand fra lekmannshold. På viktige punkter mente man den avvek fra gamle Pontoppidan. Den var preget av Grundtvigs "kirkelige anskuelse", og regnet alle døpte som medlemmer av kirken. Kultursynet var langt åpnere enn hos Pontoppidan, og dessuten mente kritikerne at boken åpnet for omvendelse etter døden, noe som var i sterk motsetning til den pietistiske lekmannsforkynnelsen (Thorkildsen 1996, 80-85).

Motstanden mot den omarbeidede forklaring ble etter hvert så høylydt at myndighetene - ved kongelig resolusjon av 7 . oktober 1852 - fant å måtte gjøre retrett og tillate fortsatt bruk av den eldre utgaven av Pontoppidans forklaring (Thorkildsen 1996, 85). Forklaringsstriden markerte den begynnende striden om grundtvigianismen i Norge. Også i en ansettelsessak ved Det teologiske fakultet kom motsetningene til uttrykk.

Etter Hersleb og Stenersens død var fakultetet fortsatt grundtvigiansk farget. I 1832 fikk fakultetet sin tredje faste lærerstilling, da Jacob Fr. Dietrichson (1806-1879) ble ansatt. Stenersen ble etterfulgt av sin elev og venn, Christian Nicolai Keyser (1798-1846), utnevnt til professor i 1836. Herslebs ettermann ble den senere biskop Jens Mathias Pram Kaurin (1804-1863), utnevnt til lektor høsten 1837 og professor fra 1843 (Morgenstierne 1911, 177, 185-186). Den nye generasjon av teologiske lærere var alle sympatisk innstilte overfor grundtvigianismen, i særlig grad Kaurin. Ved Keyser død i 1846 skulle det ansettes ny universitetslærer. I første runde var det ingen kvalifiserte søkere, og stillingen måtte utlyses på nytt. En aktuell kandidat kunne være den danske grundtvigianer og kirkehistoriker Ludvig Helveg (1818-1883). ${ }^{30}$ De teologiske studenter oppfordret imidlertid Gisle Johnson (1822-1894), som var stipendiat ved fakultetet, om å søke. Johnson ønsket imidlertid ikke å konkurrere med Helveg. Da søknadsfristen utløp, var Helveg eneste søker. Det kunne virke som saken var avgjort. Grundtvigianerne støttet naturlig nok ham, grafisk leksikon. Bd. 6 (København: Gyldendal 1980). 
men det kom samtidig til uttrykk en viss motvilje mot å ansette en utlending. Høyst sannsynlig har dette bidratt til at ansettelsen dro ut i tid (Thorkildsen 1996, 96).

Men Helveg ble allikevel ikke ansatt. Et brev fra Johnson til fakultetet skulle bli avgjørende. Johnson var på dette tidspunktet på studiereise i Tyskland, og i Leipzig hadde han møtt den kjente teologen og orientalisten Carl Paul Caspari (1814-1892). I brevet hjem til Norge skrev Johnson at Caspari vurderte å søke stillingen. Og noen dager senere forelå søknaden fra Caspari - tre uker etter at søknadsfristen var utløpt - og utvilsomt skrevet av Johnson. Det videre forløp ble at fakultetet innhentet en faglig vurdering av Helveg fra Universitetet i København. Denne var svært negativ - og det avgjorde saken. Man valgte å ansette Caspari (Thorkildsen 1996, 96-97). Denne var en sterkt konfesjonell luthersk teolog, og ansettelsen av ham ble en styrking av denne strømningen.

At Helveg ikke fikk stillingen ved i Christiania, innebar en tapt mulighet for den grundtvigianske retningen i Norge. Da Gisle Johnson i 1849 ble ansatt som lektor i teologi ved fakultetet, førte det til en markant endring av fakultetsprofilen. Fakultetet ble anti-grundtvigiansk. Det hører med at den grundtvigiansk innstilte professor Kaurin i 1853 valgte å forlate fakultetet til fordel for en sognepreststilling. ${ }^{31}$ Caspari og Johnson gikk begge inn for å knekke grundtvigianismen som teologisk og kirkelig retning i Norge. Ifølge Johnson var grundtvigianismen "i det væsentlige ligesaa uluthersk, som Katolicismen, Kalvinismen, Baptismen eller hvilken som helst anden vor lutherske Kirke aabenbar fremmed og fiendlig Retning" (sitert etter Molland 1979, 133). Dette skal vi imidlertid ikke gå nærmere inn på her. Det hører med til en ny fase i Det teologiske fakultets historie.

\section{Sammenfatning}

Etableringen av et eget universitet i Norge skjedde kort før adskillelsen mellom Danmark og Norge. For Norge ble institusjonen avgjørende for den nasjonale utviklingen. Det teologiske fakultet var blant de opprinnelige fakultetene ved universitetet. Teologi og jus utgjorde "brødstudiene" - og Det teologiske fakultet var i de første årene det største av de fire fakultetene ved det nyopprettede universitetet. De kulturelle impulsene fra Danmark var fortsatt betydelige lenge etter unionens opphør. Det teologiske fakultet - og også universitetet som 
sådan - ble i stor grad drevet etter mønster fra Universitetet i København. Først i 1824 fikk Universitetet i Christiania sin egen fundas.

Det teologiske fakultet i Christiania ble gjennom sine to første lærere, S.B. Hersleb og S.J. Stenersen, grundtvigiansk preget. Dette var Grundtvigs bibelkristne fase - og de to norske universitetslærerne stod begge i brevkontakt med ham. Grundtvig var tidlig på tale som universitetslærer i Christiania. Hersleb og Grundtvig kjente dessuten hverandre fra København. Forholdet til Grundtvig ble imidlertid distansert da han vant fremt til "den kirkelige Anskuelse" midt i 1820årene. Men blant yngre teologer fikk grundtvigianismen en viss inngang. En ny generasjon av teologiske lærere etter Hersleb og Stenersen sympatiserte med den grundtvigianske retning.

Til tross for spenningene i forhold til Grundtvig er det allikevel rimelig å karakterisere fakultetet helt frem til slutten av 1840-årene som moderat grundtvigiansk. Men da skjedde et nytt generasjonsskifte og samtidig et markant ideologisk skifte ved Det teologiske fakultet. Med C.P. Caspari og Gisle Johnson som de dominerende skikkelsene ved fakultetet fikk dette nå et skarpt antigrundtvigiansk preg. 